\title{
An interplay of genetic and environmental factors in familial hepatitis and myasthenia gravis
}

\author{
SENGA WHITTINGHAM, IAN R. MACKAY, AND Z. S. KISS \\ From the Clinical Research Unit, The Walter and Eliza Hall Institute of Medical Research, and \\ The Royal Melbourne Hospital, Melbourne, Victoria, Australia
}

SUMMARY A family is described in which there occurred two cases of the lupoid type of active chronic hepatitis with cirrhosis, one of chronic persistent hepatitis, and one of myasthenia gravis. The two cases of lupoid hepatitis were in the proposita, a schoolgirl aged 16 years, and her great-aunt aged 69 years whom she had never met. The case of myasthenia gravis was that of the father. The whole family, except the great-aunt, had been exposed to an epidemic of infectious hepatitis five years previously, and the girl and her brother had contracted this disease. The schoolgirl later developed active chronic hepatitis while her brother had chronic persistent hepatitis without immunological concomitants.

Apart from coincidence, some combination of three processes was required to account for the illnesses in this family: a genetic predisposition to chronic liver disease in particular, a genetic predisposition to autoimmune reactions in general, and a 'triggering' effect of infection with the hepatitis virus.

This account of lupoid hepatitis and myasthenia gravis occurring in a family illustrates a complex interplay of environment and heredity in the pathogenesis of these presumed autoimmune diseases. The proposita was a schoolgirl aged 16 years who presented with lupoid hepatitis: her great-aunt had chronic liver disease, her father had myasthenia gravis, and two brothers had hepatosplenomegaly but no immunological anomalies. These illnesses, except that of the great-aunt, occurred after the family was exposed to an epidemic of infectious hepatitis in a small country town.

\section{Methods}

The methods for the biochemical tests of liver function were those described by Mackay and Wood (1962), for autoimmune serological reactions those described by Whittingham and
Mackay (1969), and for the hepatitis antigen those described by Mathews and Mackay (1970).

\section{Case Reports}

The family tree for the C. family is shown in Figure 1.

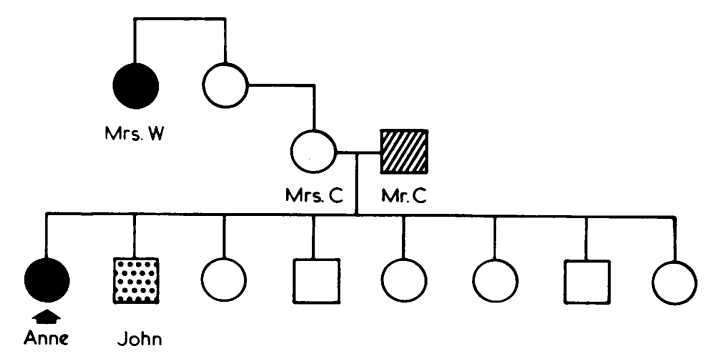

Fig. 1 Family tree showing the proposita, Anne, who had lupoid hepatitis, a great-aunt, Mrs W., who had cryptogenic cirrhosis, a brother, John, who had chronic persistent hepatitis, and the father, $\mathrm{Mr} \mathrm{C}$., who had myasthenia gravis. 


\section{PROPOSITA}

Anne C. was a schoolgirl aged 16 years. She became jaundiced for two weeks in 1962 when aged 11 years and the family doctor diagnosed infectious hepatitis which was then epidemic in the town. Although she appeared to recover completely she had several episodes of malaise each year thereafter and her menses commenced late at 14 years, occurred with scanty blood loss every second month, and ceased after one year. In 1967 she had jaundice, pains in the knees and elbows, and mild diarrhoea for one month. The liver was tender and enlarged $5 \mathrm{~cm}$ below the costal margin, the spleen was impalpable, there were spider naevi on the arms and face, acne on the face and chest, and there were no KaiserFleischer rings.

\section{Investigations}

Serum glutamic oxaloacetic transaminase (GOT) was found to be $300 \mathrm{IU} / 1$ using the Babson method; serum bilirubin was $1.7 \mathrm{mg} / 100 \mathrm{ml}$; serum albumin $3.2 \mathrm{~g} / 100 \mathrm{ml}$; serum gamma globulin $5.8 \mathrm{~g} / 100 \mathrm{ml}$; erythrocyte sedimentation rate (ESR, Westergren) $133 \mathrm{~mm}$ in one hour; prothrombin time $27 \%$ of normal; retention of a standard dose $(5 \mathrm{mg} / \mathrm{kg})$ of bromsulphalein (BSP) $14 \%$ after $45 \mathrm{~min}$; serum alkaline phosphatase 15 King-Armstrong (KA) units; haemoglobin $10.5 \mathrm{~g} / 100 \mathrm{ml}$; the red blood cell count and morphology were normal; serum urea $34 \mathrm{mg} / 100$ $\mathrm{ml}$; serum copper oxidase activity was normal. The LE cell test was initially negative but became transiently positive later. The immunofluorescence test for antibody to smooth muscle was positive, the titre of antibody to granulocyte nuclei was 1,000 , but tests for antibodies to nuclei of lymphocytes and tissue cells were

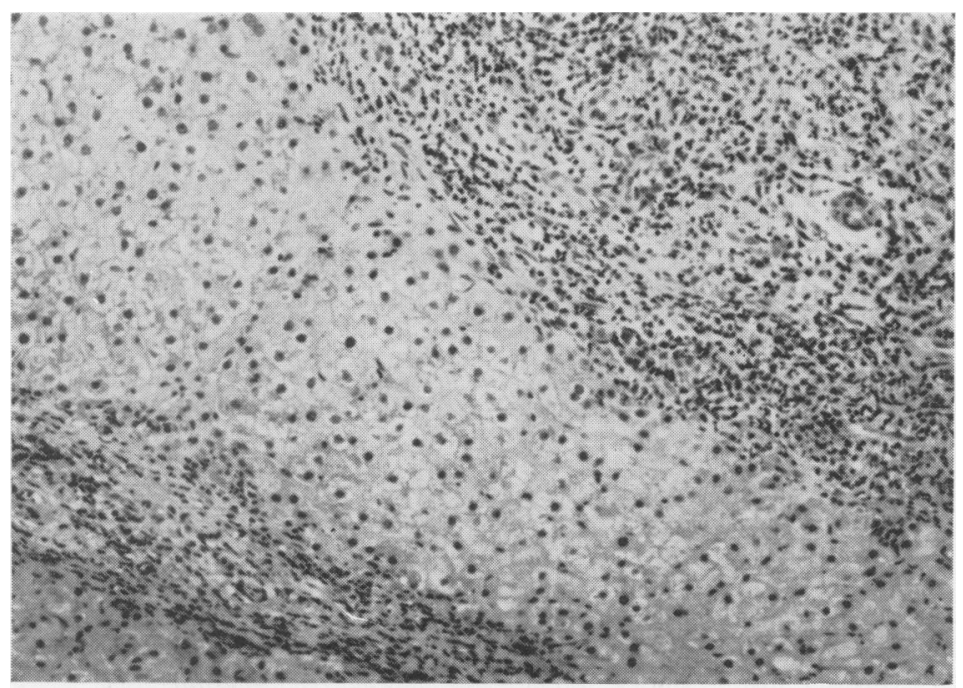

Fig. 2. Liver biopsy of Anne C., showing pronounced fibroblastic reaction with many lymphoid cells. Haematoxylin and eosin, $\times 120$. negative. Immunofluorescence tests were negative for antibodies to mitochondria, skeletal muscle, thymic myoid cells, gastric and thyroid antigens. The autoimmune complement-fixation test, Coombs test, sheep cell agglutination test for $\stackrel{\vec{F}}{\stackrel{F}{+}}$ rheumatoid factor, Wassermann reaction, and Casoni test were all negative. The titre of serum complement of 32 was at the lower limit of our normal range (32-128). Sera obtained during 1967-1969 were negative for the hepatitis antigen (Au 1).

\section{Liver biopsy}

A liver biopsy (Fig. 2) one month after prednisolone was given showed loss of architecture with extensive proliferation of fibroblasts and bile ducts in portal areas, some 'piecemeal' necrosis of liver cells, and pronounced lymphoid infiltration with groups of plasma cells at the edge of the fibrous tissue.

\section{Diagnosis}

A lupoid type of active chronic hepatitis with progression to cirrhosis was diagnosed.

\section{Treatment and progress}

The proposita was given $40 \mathrm{mg}$ prednisolone daily for two weeks and the serum levels of GOT and gamma globulin fell sharply. The dose of prednisolone was reduced quickly to $15 \mathrm{mg}$ daily, but relapse occurred and the LE cell test then became positive. She was then given prednisolone $10 \mathrm{mg}$ daily and azathioprine $100 \mathrm{mg}$ daily and thereafter improved. After one year of treatment she felt well, was fully employed, and her menses were regular. The serum GOT was 48 units, serum albumin $4 \cdot 1 \mathrm{~g} / 100 \mathrm{ml}$, serum gamma globulin $3.0 \mathrm{~g} / 100 \mathrm{ml}$, and the BSP retention was $2 \%$. The test for antibody to smooth muscle remained positive but the titre of antinuclear antibody to granulocyte nuclei had fallen from 1,000 to 1 . She was still well in 1970.

\section{GREAT-A UNT}

Mrs W., aged 69 years, had never met Anne; she did not reside in the same town as the $C$. family, had no known contact with infectious hepatitis, and denied drinking alcohol. In February 1965 she was found to have hepatosplenomegaly by her doctor when she had a 'bilious attack' with vomiting and jaundice. She apparently recovered, but in November 1965 the abdomen became swollen. Examination showed ascites, enlargement of the liver $5 \mathrm{~cm}$ and of the spleen $3 \mathrm{~cm}$ below the costal margin, several spider naevi, palmar erythema, and hepatic foetor.

\section{Investigations}

Serum GOT was $70 \mathrm{IU} /$ litre; serum bilirubin 1.8 $\mathrm{mg} / 100 \mathrm{ml}$; serum albumin $2.0 \mathrm{~g} / 100 \mathrm{ml}$; serum gamma globulin $3.2 \mathrm{~g} / 100 \mathrm{ml}$; ESR $105 \mathrm{~mm}$ in 


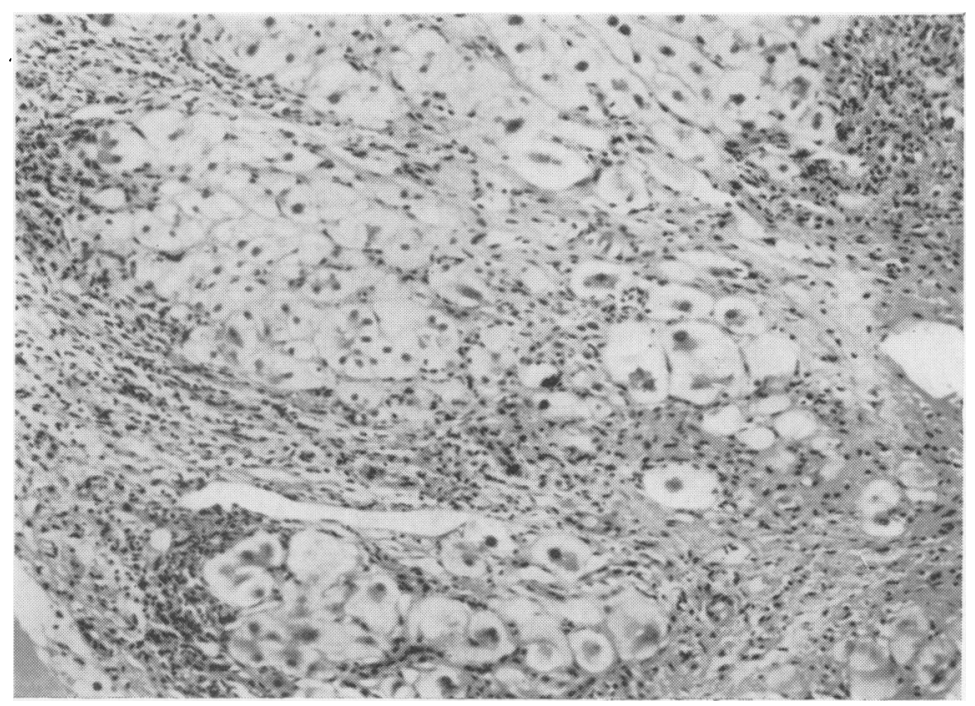

Fig. 3. Liver biopsy of Mrs W. showing established cirrhosis and a small nodule of liver cells showing 'ballooning' and necrosis; there are moderate numbers of lymphoid cells. Haematoxylin and eosin, $\times 120$.

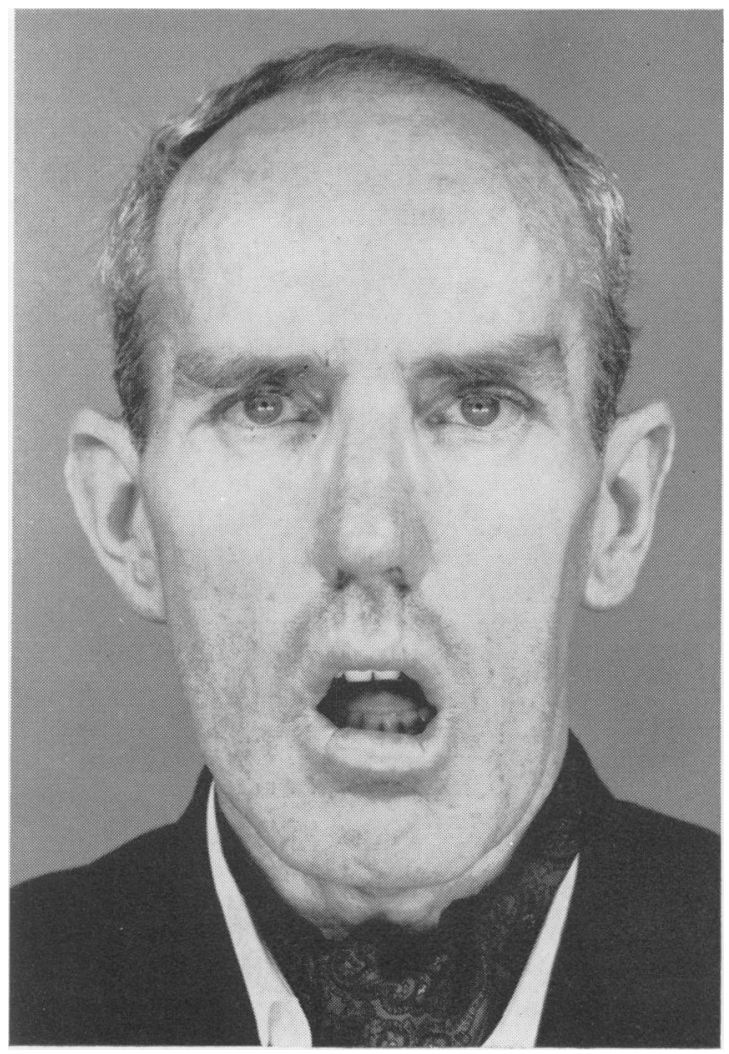

Fig. 4. Mr C., father of Anne, had myasthenia gravis with bilateral facial weakness. one hour; prothrombin time $26 \%$ of normal; serum alkaline phosphatase $20 \mathrm{KA}$ units. The LE cell test was positive. Immunofluorescence tests showed antibodies to nuclei of granulocytes (titre 100), lymphocytes and tissue cells (titre 100), smooth muscle and gastric parietal cells, but not to mitochondria, skeletal muscle cells, thymic myoid cells, and thyroid antigens. The test for autoimmune complement fixation, Coombs test, sheep cell agglutination test for rheumatoid factor, Wassermann reaction, and Casoni test were negative. Sera obtained during 1967 were negative for the hepatitis antigen (Au 1).

\section{Liver biopsy}

Fibrous bands divided the liver into nodules of varying size giving a cirrhotic pattern. There was 'piecemeal' necrosis, 'ballooning' of liver cells and a moderate infiltrate of lymphoid cells (Fig. 3).

\section{Diagnosis}

Coarsely nodular 'cryptogenic' cirrhosis, presumably a sequel to the lupoid type of active chronic hepatitis, was diagnosed.

\section{Treatment and progress}

The subject was given diuretic drugs. After one year the titre of antinuclear antibody had fallen to 1 and antibodies to smooth muscle were no longer demonstrable. Death occurred from liver failure in April 1967. A necropsy was not performed.

\section{FATHER}

Mr C., aged 43 years, was not ill during the hepatitis epidemic in 1962, but about three months later he became unable to purse his lips. In 1965 he lost weight, had increasing weakness of the facial and pharyngeal muscles, his speech became slurred and his legs felt weak: these disabilities increased as the day progressed. Examination in 1967 showed pronounced weakness and wasting of the facial muscles bilaterally, ptosis, and dribbling of saliva (Fig. 4). There was no hepatosplenomegaly or other evidence of chronic liver disease.

\section{Investigations}

Serum GOT $16 \mathrm{IU} / \mathrm{l}$; serum albumin $4.4 \mathrm{~g} / 100$ $\mathrm{ml}$; serum gamma globulin $1.3 \mathrm{~g} / 100 \mathrm{ml}$; ESR $23 \mathrm{~mm}$ in one hour. The immunofluorescence test was positive for antibodies to nuclei of granulocytes (titre 100) but not to other cell nuclei. All other autoimmune serological reactions were negative including those with antigens of smooth muscle, mitochondria, skeletal muscle cells, and thymic myoid cells. Serum obtained in 1967 was negative for the hepatitis antigen (Au 1). The electromyogram showed a fall in amplitude of successive action potentials, typical of myasthenia gravis. There was a transient increase in strength 
after an intravenous injection of edrophonium (Tensilon). There was no evidence of thymoma by pneumomediastinography.

\section{Treatment and progress}

Maintenance treatment with pyridostigmine was beneficial. Thymectomy was not performed because of advanced myopathy. In 1970 he remained in moderate health.

\section{BROTHER}

John C., aged 13 years, also became ill in 1962. He had anorexia, vomiting, epigastric pain, and jaundice, and the diagnosis by the family doctor was infectious hepatitis. Subsequently he had three to four episodes of malaise, abdominal pain, and vomiting each year. Examination in 1967 showed the liver to be enlarged $5 \mathrm{~cm}$ below the costal margin and the spleen $3 \mathrm{~cm}$.

\section{Investigations}

Serum GOT $90 \mathrm{IU} / \mathrm{l}$; serum bilirubin $0.4 \mathrm{mg} / 100$ $\mathrm{ml}$; serum albumin $4.3 \mathrm{~g} / 100 \mathrm{ml}$; serum gamma globulin $1.3 \mathrm{~g} / 100 \mathrm{ml}$; ESR $8 \mathrm{~mm}$ in one hour; prothrombin time $80 \%$ of normal; BSP retention $12 \%$; serum alkaline phosphatase $28 \mathrm{KA}$ units. All autoimmune serological tests were negative, including those for antibodies to antigens of cell nuclei, smooth muscle and mitochondria. Sera obtained during 1967 were negative for the hepatitis antigen ( $\mathrm{Au} \mathrm{1).}$

\section{Liver biopsy}

The architecture was normal, there was minimal fibrosis, but there were small infiltrations of lymphoid cells in the portal tracts, multinucleated liver cells indicative of regeneration, and prominence of Kupffer cells (Fig. 5).

\section{Diagnosis}

Chronic persistent hepatitis (Becker, Scheuer, Baptista, and Sherlock, 1970), perhaps equivalent to the condition described as 'persisting acute

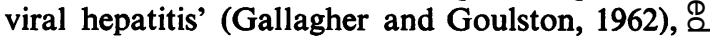
was diagnosed.

Treatment and progress

No treatment was given and in 1970 he was well. $\vec{\omega}$

\section{MOTHER}

Mrs. C., aged 46 years, in 1962 had infectious. hepatitis from which she fully recovered. Physical examination and laboratory investigations in $\stackrel{\infty}{\vec{\prime}}$ 1967 showed no evidence of liver disease. All $\vec{\circ}$

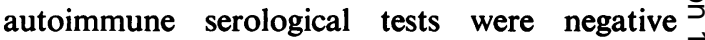
apart from a weakly positive reaction to thyroid epithelial cells. Sera obtained in 1967 were negative for the hepatis antigen (Au 1). She was in good health.

\section{SIBLINGS}

M.C., P.C., C.C., H.C., S.C., and E.C., aged $11,10,8,7,5$, and 3 years respectively, did not $\sum^{\circ}$ develop clinical infectious hepatitis in 1962 or later and in 1967 were mostly in good health. C.C. had syndactyly, H.C. had strabismus, and in 1967 S.C. had attacks of vomiting and his liver and spleen were palpable. All autoimmune serological tests and tests for the hepatitis antigen (Au 1) in these siblings were negative.

\section{Discussion}

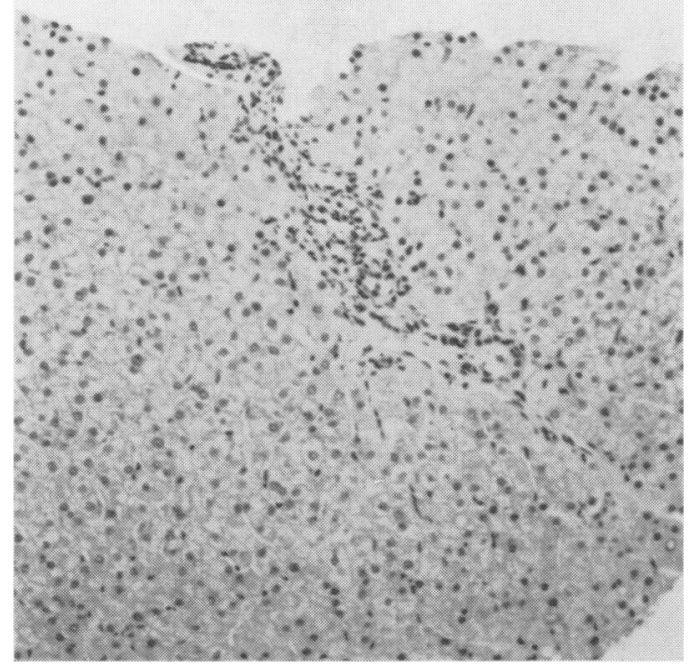

Fig. 5. Liver biopsy of John C. showing normal architecture, prominence of Kupffer cells, and a mild lymphoid reaction in a portal tract. Haematoxylin and eosin, $\times 90$.
The C. family is unusual in that Anne, the proposita, aged 16 years, and her maternal great- $\frac{\text { ? }}{2}$ aunt who had never met or lived in the same $\rightarrow$ family group, had the lupoid type of activechronic hepatitis, her father had myasthenia gravis, and $\bar{N}$ her brother had chronic persistent hepatitis. The $\sigma$ lupoid type of active chronic hepatitis and $\tilde{O}$ myasthenia gravis both fulfil many of the $\underset{\omega}{ }$ 'immunological markers' (Mackay and Burnet, 1963) for autoimmune diseases: there are specific 0 autoimmune serological reactions, ie, smooth $\overparen{\Phi}$ muscle antibodies in lupoid hepatitis and $\stackrel{?}{+}$ 'myoid' antibodies in myasthenia gravis, ab- ㄲ normal lymphoid reactions in the liver in lupoid hepatitis and the thymus in myasthenia gravis, $\stackrel{\square}{\square}$ and both diseases show clinical and serological $\stackrel{\mathbb{Q}}{\varrho}$ 'overlap', within individuals and families, with other presumed autoimmune diseases (Kunkel 8 and Tan, 1964). Chronic persistent hepatitis on the other hand has none of the stigmata of an autoimmune process.

The propositions required to account for the 
illnesses of the C. family are as follows: (1) a familial predisposition to chronic liver disease which occurred in two siblings and their greataunt; (2) a possible genetic predisposition to autoimmune processes, including lupoid hepatitis, in the proposita and a great-aunt, and myasthenia gravis in the father; (3) the occurrence of liver disease and myasthenia gravis after exposure of the family to an epidemic of infectious hepatitis.

FAMILIAL PREDISPOSITION TO CHRONIC HEPATITIS AND/OR CIRRHOSIS OF THE LIVER Such familial predisposition is unusual except in cases of liver disease resulting from an inborn error of metabolism. Excluding these, Maddrey and lber (1964) described eight families in which there were two or more siblings with 'familial' cirrhosis not attributable to inheritable metabolic disorders affecting the liver, and they concluded from their own observations and from similar published cases that cirrhosis in families could be genetically determined. They attributed this to a recessive gene which had "low or variable penetrance causing abiotrophy' or which 'affected the ability of the liver to withstand the insults of hepatitis or increased alcohol'. The families in this study were not tested for autoantibodies. However, the occurrence of myasthenia gravis in the C. family is not accounted for if familial predisposition to chronic liver disease were the sole proposition.

GENETIC PREDISPOSITION TO AUTOIMMUNE REACTIONS

Genetic predisposition is recognized in the 'thyrogastric' group of autoimmune diseasespernicious anaemia, thyroiditis, and Addison's disease (Velde, Abels, Anders, Arends, Hoedemaeker, and Nieweg, 1964; Wangel, Callender, Spray, and Wright, 1968; Whittingham, Ungar, Mackay, and Mathews, 1969). There is also an increased prevalence of serological abnormalities, including antinuclear antibodies and hypergammaglobulinaemia, in family members of patients with systemic lupus erythematosus (Fennell, Maclachlan, and Rodnan, 1962; Pollak, 1964; Holborow and Johnson, 1964; Leonhardt, 1964) and rheumatoid arthritis (Lawrence and Ball, 1958; Ziff, Schmid, Lewis, and Tanner, 1958). These predispositions are attributable to a genetically determined disorder of immunological tolerance to specific groups of antigens (Whittingham et al, 1969). The two family studies relating to predisposition of autoimmune disease affecting the liver concern an association between lupoid hepatitis and familial hypergammaglobulinaemia (Cavell and Leonhardt, 1965) and the increased prevalence of antinuclear antibodies and rheumatoid factor in siblings of probands with cirrhosis (Elling, Ranløv, and Bildsøe, 1966).
In relation to the $\mathrm{C}$. family, both myasthenia gravis and 'certain liver diseases' were included by Kunkel and Tan (1964) among 'disorders linked with clinical, laboratory and genetic studies to systemic lupus erythematosus'. A single case of coexisting myasthenia gravis and lupoid hepatitis was reported by Alarcón-Segovia, Galbraith, Maldonado, and Howard (1963) and later by Galbraith, Summerskill, and Murray (1964); thymic germinal centres were observed in one case of cirrhosis by Corridan (1963) and a case of thymoma with lupoid hepatitis was reported by Linke (1965). We know of no reported cases of active chronic hepatitis and myasthenia gravis within a family, but can cite the case (unpublished) of a woman from our clinic with lupus erythematosus who had thymectomy for myasthenia gravis 20 years previously, at which time her brother developed active chronic hepatitis which ended fatally after three years. However, the occurrence of chronic persistent hepatitis in one member of the C. family is not explained by genetic predisposition to autoimmune reactions as the sole proposition.

EXPOSURE OF THE C. FAMILY TO THE EPIDEMIC OF INFECTIOUS HEPATITIS There are no definite grounds for stating that the hepatitis virus initiates chronic liver disease, autoimmune or otherwise, as judged by six detailed retrospective studies (Zieve, Hill, Nesbitt, and Zieve, 1953; Neefe, Gambescia, Kurtz, Smith, Beebe, Jablon, Reinhold, and Williams, 1955; Cullinan, King, and Rivers, 1958; Nefzger and Chalmers. 1963; Chuttani, Sidhu, Wig, Gupta, and Ramalingaswami, 1966; Franken, Amelung, Garke, Pohle, Liebermeister, and Deupman, 1967) involving approximately 3,500 subjects with acute infectious hepatitis; however, certain of these surveys included male soldiers who would be less likely to develop active chronic hepatitis than young women. On the other hand there is a strong impression that acute infective hepatitis does initiate postnecrotic cirrhosis (Klatskin, 1958), active chronic hepatitis (Sherlock, 1969), and lupoid hepatitis (Mackay and Whittingham, 1967); thus hepatitis virus infection could be the initiating event in the case of the proposita and her brother, with the different course of the liver disease thereafter being attributable to a different host response. Whilst there have been no suggestions that myasthenia gravis is initiated by a viral infection within the thymus, this might fit with certain trends of opinion in regard to the causation of autoimmune disease (van Loghem, 1965; Fudenberg 1966; Williams, Kenyon. and Huntley, 1968). However the fact that one family member, the great-aunt, had lupoid hepatitis yet had no known exposure to the hepatitis epidemic negates this as the sole explanation for the family illnesses. 
Thus, without invoking coincidence, none of the above three concepts alone suffices to account for the aggregation of diseases-lupoid hepatitis, chronic persistent hepatitis, and myasthenia gravis -in the C. family Accordingly, we must invoke the combined influence of the three processes: a genetic predisposition to chronic liver disease in particular, a genetic predisposition to autoimmune reactions in general, and a 'triggering' effect of infection with the hepatitis virus.

We thank Dr J. A. Forbes who referred Anne C. and John C. to our Unit, and Dr C. G. Batten, the C. family doctor, who willingly assisted our study. We also thank Dr A. C. Schweiger for making available details of the case of $\mathrm{Mr} \mathrm{C}$., and Professor R. R. H. Lovell for making available details of the case of Mrs W. We thank Dr B. Wadham for photomicrographs, $\mathrm{Mr} \mathrm{R}$. Inglis for photographs, Dr C. W. Baird, Dr D. C. Cowling and Dr J. D. Mathews for undertaking certain of the laboratory procedures, and Miss Janet Irwin and Miss Heather Buchanan for technical assistance.

Two of the authors (S.W. I.R.M.) were assisted by a grant from the National Health and Medical Research Council of Australia.

\section{References}

Alarcón-Segovia, D., Galbraith, R. F., Maldonado, J. E., and Howard, F. M. (1963). Systemic lupus erythematosus following thymectomy for myasthenia gravis: Report of two cases. Lancet, 2, 662-665

Becker, M. D., Scheuer, P. J., Baptista, A., and Sherlock, S. (1970). Prognosis of chronic persistent hepatitis. Lancet, 1, 53-56

Cavell, B., and Leonhardt, T. (1965). Hereditary hypergammaglobulinemia and lupoid hepatitis. Acta med. scand., 177, 751-759.

Chuttani, H. K., Sidhu, A. S., Wig, K. L., Gupta, D. N., and Ramalingaswami, V. (1966). Follow-up study of cases from the Delhi epidemic of infectious hepatitis of 1955-56. Brit. med. J., 2, 676-679.

Corridan, M. (1963). The thymus in hepatic cirrhosis. J. clin. Path., 16, 445-447.

Cullinan, E. R., King, R. C., and Rivers, J. S. (1958). The prognosis of infective hepatitis. A preliminary account of a long-term follow-up. Brit. med. J., 1, 1315-1317.

Elling, P., Ranløv, P., and Bildsøe, P. (1966). A genetic approach to the pathogenesis of hepatic cirrhosis. A clinical and serological study. Acta med. scand., 179, 527-533.

Fennell, R. H., Maclachlan, M. J., and Rodnan, G. P. (1962). The occurrence of antinuclear factors in the sera of relatives of patients with systemic rheumatic disease (abstr.) Arthr. and Rheum., 5, 296.

Franken, F. H., Amelung, D., Garke, P., Pohle, D., Liebermeister, H., and Deupman, F. J. (1967). Post-hepatic cirrhosis of the liver: a follow-up study. Germ. med. Mth., 12, 305-311.

Fudenberg, H. H. (1966). Immunologic deficiency, autoimmune disease, and lymphoma: Observations, implications, and speculations. Arthr. and Rheum., 9, 464-472.
Galbraith, R. F., Summerskill, W. H. J., and Murray, J. (1964). Systemic lupus erythematosus, cirrhosis and ulcerative colitis after thymectomy for myasthenia gravis. New Engl. J. Med., 270, 229-232.

Gallagher, N. D., and Goulston, S. J. M. (1962). Persistent acute viral hepatitis. Brit. med. J., 1, 906-908.

Holborow, J., and Johnson, G. D. (1964). Antinuclear factor in systemic lupus erythematosus. A consideration of the immunofluorescent method of detecting antinuclear antibodies with results obtained in a family study. Arthr. and Rheum., 7, 119-127.

Klatskin, G. (1958). Subacute hepatic necrosis and postnecrotic cirrhosis due to anicteric infections with the hepatitis virus. Amer. J. Med., 25, 333-358.

Kunkel, H. G., and Tan, E. M. (1964). Autoantibodies and disease. Advanc. Immunol., 4, 351-395.

Lawrence, J. S., and Ball, J. (1958). Genetic studies on rheumatoid $\vec{\odot}$ arthritis. Ann. rheum. Dis., 17, 160-168.

Leonhardt, T. (1964). Family studies in systemic lupus erythematosus. Acta. med. scand., 176, Suppl. 416.

Linke, A. (1965). Thymustumor mit lupoider Hepatitis. Schweiz. med. Wschr., 95, 1492-1494.

Loghem, J. J. van (1965). Viral infection and idiopathic autoimmune diseases: A hypothesis. Vox Sang. (Basel), 10, 1-5.

Mackay, I. R., and Burnet, F. M. (1963). Autoimmune Diseases: Pathogenesis, Chemistry and Therapy, p. 123. Thomas, Springfield, Illinois.

Mackay, I. R., and Whittingham, S. (1967). 'Auto-immune' chronic hepatitis. Postgrad. Med., 41, 72-83.

Mackay, I. R., and Wood, I. J. (1962). Lupoid hepatitis: a comparison of 22 cases with other types of chronic liver disease. Quart. J. Med., 31, 485-507.

Maddrey, W. C., and Iber, F. L. (1964). Familial cirrhosis: A clinical and pathological study. Ann. intern. Med., 61, 667-679.

Mathews, J. D., and Mackay, I. R. (1970). Australia antigen in chronic hepatitis in Australia. Brit. med. J., 1, 259-261.

Neefe, J. R., Gambescia, J. M., Kurtz, C. H., Smith, H. D., Beebe, G. W., Jablon, S., Reinhold, J. G., and Williams, S. C. (1955). Prevalence and nature of hepatic disturbance following acute viral hepatitis with jaundice. Ann. intern. Med., 43, 1-32.

Nefzger, M. D., and Chalmers, T. C. (1963). The treatment of acute infectious hepatitis. Ten-year follow-up study of the effects of diet and rest. Amer. J. Med., 35, 299-309.

Pollak, V. E. (1964). Antinuclear antibodies in families of patients with systemic lupus erythematosus. New Engl. J. Q Med., 271, 165-171.

Sherlock, S. (1969). Discussion of the paper by R. W. McCollum, 'The natural history of hepatitis'. Bull. N.Y. Acad. Med. 45, 138-142.

Velde, K. te, Abals, J., Anders, G. J. P. A., Arends, A., Hoedemaeker, P. J., and Nieweg, H. O. (1964). A family study of pernicious anemia by an immunologic method. J. Lab. clin. Med., 64, 177-187.

Wangel, A. G., Callender, S. T., Spray, G. H., and Wright, R. (1968). A family study of pernicious anaemia. II. Intrinsic factor secretion, vitamin $\mathbf{B}_{1 z}$ absorption and genetic aspects of gastric autoimmunity. Brit. J. Haemat., 14, 183-204.

Whittingham, S., and Mackay, I. R. (1969). Laboratory methods for diagnosis of autoimmune disease. Med. J. Aust., 1, 1200-1205.

Whittingham, S., Ungar, B., Mackay, I. R., and Mathews, J. D. I (1969). The genetic factor in pernicious anaemia: A family study in patients with gastritis. Lancet, 1, 951-954.

Williams, R. C., Jr., Kenyon, A. J., and Huntley, C. C. (1968). N Immunoglobulins, viruses and speculation on their interrelationship in certain human and animal disease states. Blood, 31, 522-535.

Zieve, L., Hill, E., Nesbitt, S., and Zieve, B. (1953). The incidence of residuals of viral hepatitis. Gastroenterology, 25, 495-531.

Ziff, M., Schmid, F. R., Lewis, A. J., and Tanner, M. (1958). Familial occurrence of rheumatoid factor. Arthr. and Rheum., 1, 392-399.

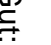

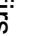

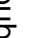

